\title{
A HIGH ALTITUDE ARCHAEOLOGICAL SURVEY IN NORTHERN CHILE
}

\author{
RECONOCIMIENTO ARQUEOLÓGICO DE MONTAÑAS ANDINAS \\ EN EL NORTE DE CHILE
}

\author{
Johan Reinhard*
}

\begin{abstract}
This paper presents the results of an investigation of ten mountains undertaken in 1983 in Lauca and Isluga National Parks in northern Chile. Archaeological sites were surveyed on five of the summits and ethnographic information was collected in villages located near them. An Inca figurine, made out of mullu shell (spondylus) was discovered on the surface at one of the sites. The survey helps extend our knowledge of the distribution and types of archaeological sites in northern Chile.

Key words: Inca, Lauca, Isluga, Parinacota, mountain worship, spondylus.

Se presentan los resultados de la exploración de 10 montañas localizadas en los parques nacionales Lauca e Isluga, en el norte de Chile, realizado durante 1983. Los sitios arqueológicos fueron explorados y registrados en cinco de las montañas revisadas. Información etnográfica fue recopilada en las comunidades cercanas. Una figurina de origen inca, tallada en concha de mullu (spondylus) fue descubierta en la superficie de uno de estos sitios. Los resultados de este estudio amplían nuestro conocimiento respecto de la distribución y tipología de los sitios arqueológicos en el norte de Chile vinculado a la prehistoria del período Inca.

Palabras claves: Inca, Lauca, Isluga, Parinacota, culto a la montaña, spondylus.
\end{abstract}

Mountain worship has long been known to play an important role in the traditional beliefs of Andean peoples. Archaeological remains have been found on several high mountains in the southern Andes, and these demonstrate that mountains also played an important role in prehispanic cultures (Reinhard 1983). In some parts of northern Chile mountain deities are still today invoked in rituals both in communal and in individual worship (Reinhard and Sanhueza 1982; Martínez 1976; Barthel 1959). When I began research in 1983 in Chile's northernmost province of Parinacota, no high altitude ruins had been reported for the region, despite it having several mountains over 5,000 $\mathrm{m}$. It was primarily for this reason that a project was developed to search for ruins on the more prominent peaks and also to investigate some of the lower mountains noted in legends of the traditional inhabitants ${ }^{1}$. At the same time, this had the advantage of extending our knowledge of archaeological sites that are situated in the national parks of the region, Lauca and Isluga ${ }^{2}$ (Figure 1).

\section{Volcán Taapaca $\left(18^{\circ}{ }^{\circ} 07 ’ S, 69^{\circ} 30^{\prime} \mathrm{W}\right)$}

Ruins were observed both on and near the summit of Cerro Taapaca $(5,815 \mathrm{~m} / 19,073$ '). While ascending the northwest ridge, my climbing companion Rob Blatherwick encountered ruins on ca. $200 \mathrm{~m}$ from the actual summit and ca. $50 \mathrm{~m}$ lower in altitude (Figure 2). Although utilized in recent times, most of these structures were likely built during the Inca period, since we found an Inca figurine on the summit itself, and the construction of artificial platforms on mountains is generally considered an Inca trait (Raffino 1981).

We found wood on the summit and a very crude outline of stones that was barely visible (Figure 3 ). Its outer dimensions were $162 \mathrm{~cm}$ x $256 \mathrm{~cm}$, but it was difficult to discern if it was originally meant to represent a circle or a rectangle. In the northern corner of this "structure" some cloth was seen. Being exposed to the weather, it was in a poor state of preservation ${ }^{3}$. While extracting some of the threads that had been separated from the cloth, I came across a figurine made of spondylus seashell $3 \mathrm{~cm}$ in the soil. The male figurine was carved in a typically Inca fashion (Figure 4). The spondylus is found in the warm waters off Ecuador and was considered indispensable in ceremonies for rain in the Inca period, even being considered more valuable than gold (Murra 1975: 257, 262).

* National Geographic Society, $114517^{\text {th }}$ Street, NW, Washington, D.C. 20036. reinhard@ johanreinhard.org. 


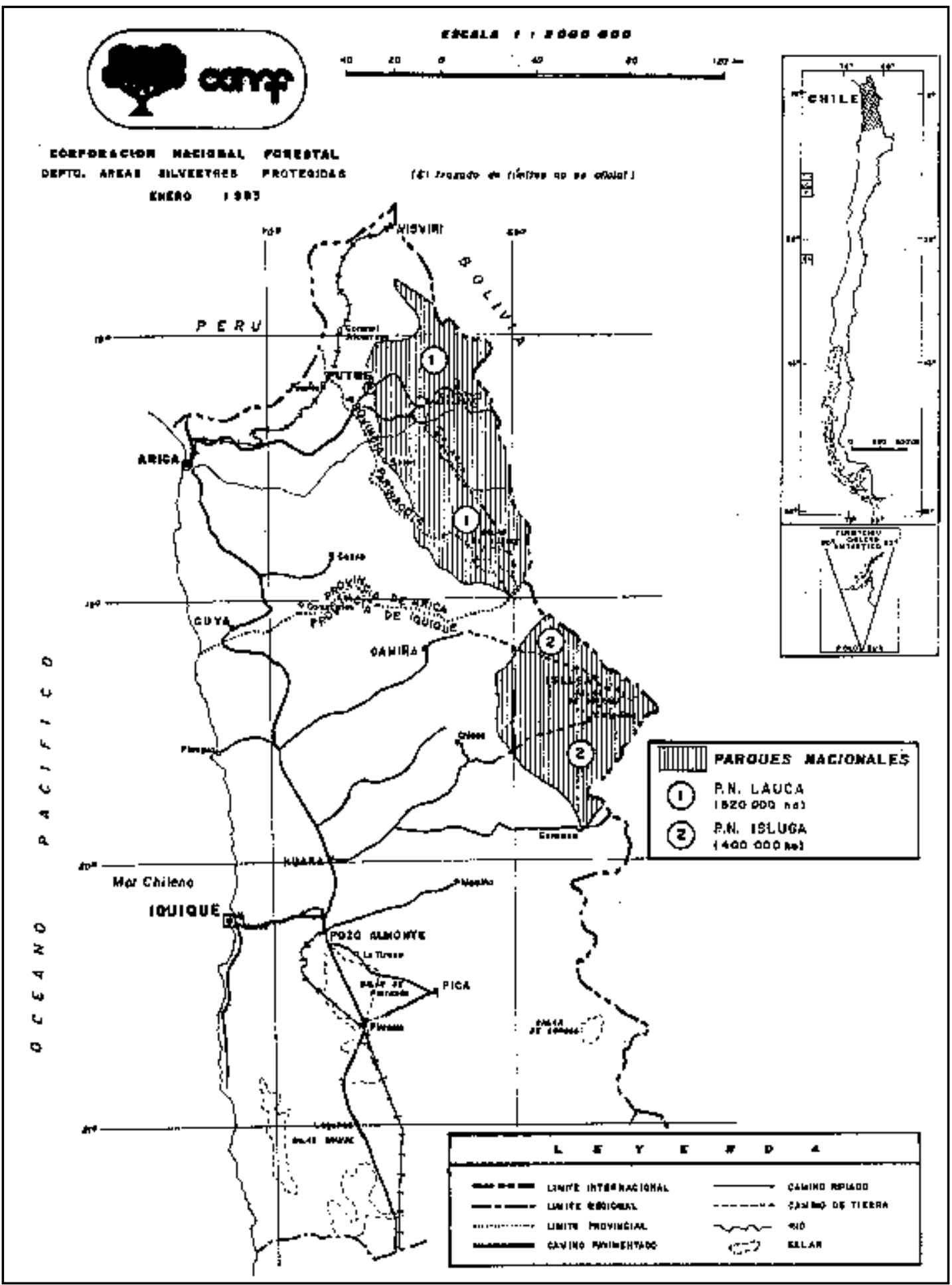

Figure 1. Lauca and Isluga National Parks surveyed area (Map of the Corporación Nacional Forestal, Depto. Areas Silvestres Protegidas).

Área reconocida en los parques nacionales Lauca e Isluga (mapa de la Corporación Nacional Forestal, Depto. Areas Silvestres Protegidas). 


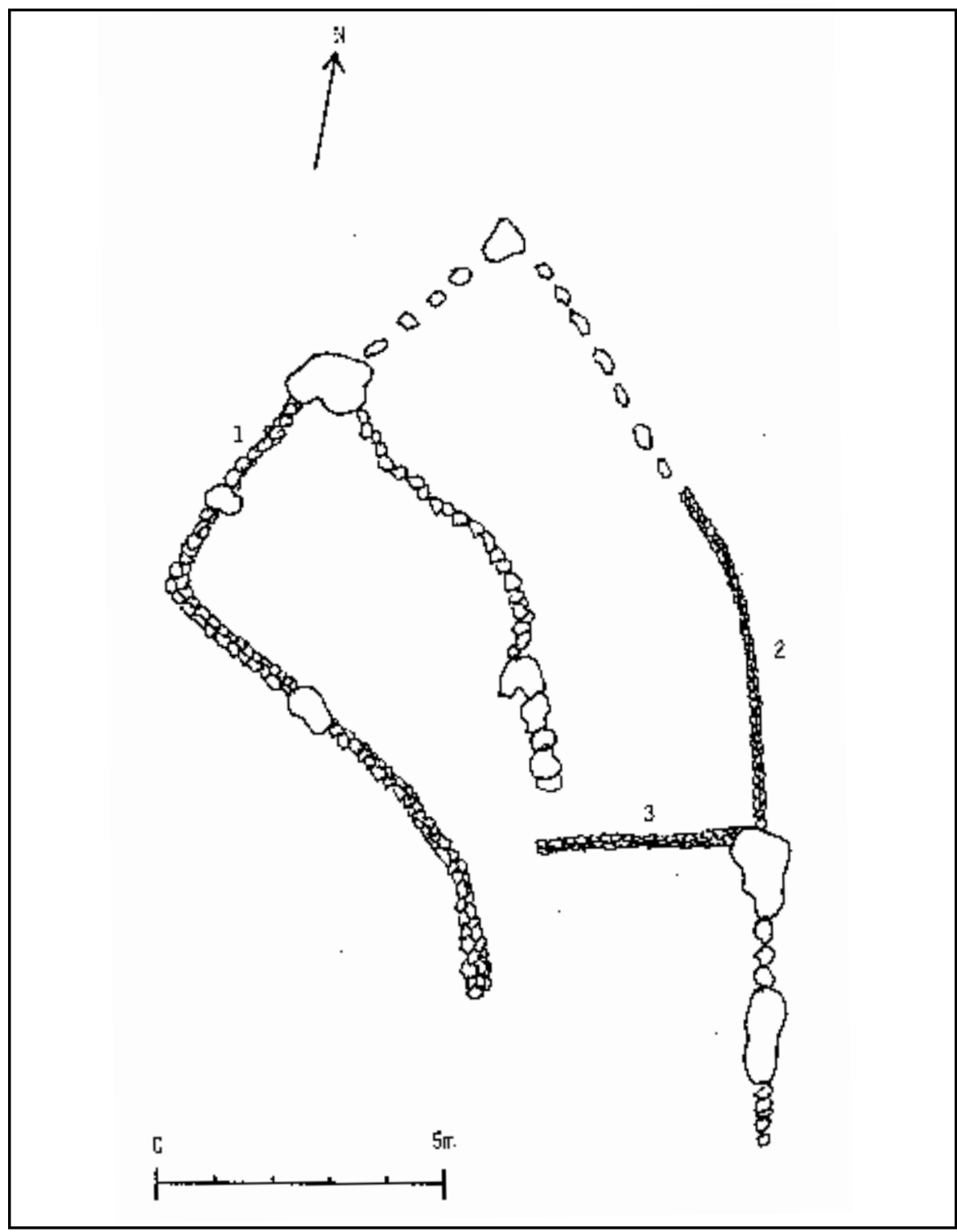

Figure 2. Plan of the ruins on the northwest ridge at ca. 5,765 m $\left(18,909^{\prime}\right)$ near the summit of Volcán Taapaca. $\mathrm{N}^{\text {os. }} 1,2$ and 3 are retaining walls.

Plano de las estructuras en el talud noroeste cerca de la cima del volcán Taapaca a ca. 5.765 m (18.909'). $N^{\text {os. }} 1,2$ y 3 corresponden a muros de contención.

I had originally chosen to climb Cerro Taapaca because of its dominant position at the source of the Río Lluta. Mountain deities are widely believed to be responsible for the fertility of plants and animals through their control of meteorological phenomena (rain, lightning, snow, hail, etc.), (Reinhard 1983). It seems possible, therefore, that the figurine was placed by the Incas for the purpose of obtaining a stable water supply.
The figurine was found lying with its head towards the southeast on a flat rock with an upright flat rock placed behind it. Based on our knowledge of such offerings at other sites, it is likely that the figurine had been originally set upright with the two rocks forming a small altar. The summit of Taapaca is reportedly normally snow covered, but we were told that the previous 14 months had gone without precipitation in the area. It may well be 


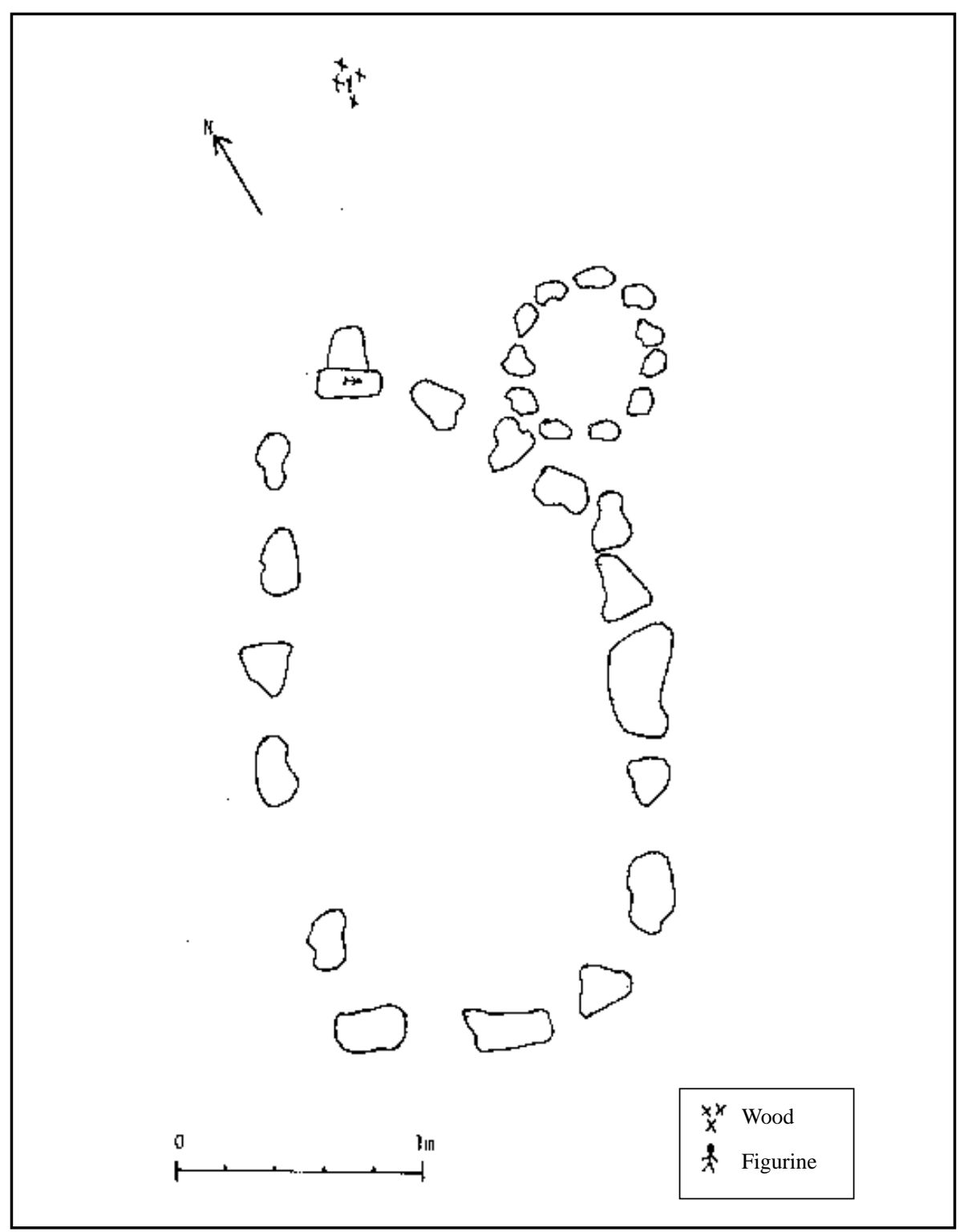

Figure 3. Plan of the summit ruin on Volcán Taapaca (5,815 m; 19,073').

Plano de la estructura en la cima del volcán Taapaca (5.815 m; 19.073').

that when the Incas made the offering the ground was frozen, and therefore they did not bury the figurine, as generally was their custom.

\section{Cerro Guane Guane $\left(18^{\circ} 09^{\prime} \mathrm{S}, 6^{\circ} 9^{\circ} 16^{’} \mathrm{~W}\right)$}

On the summit Guane Guane (ca. 5,050 m/ $16,564^{\prime}$ ) we found a few structures that appear to be of recent origin. However, it is a reasonable possibility that an artificial platform dates back to the Inca period (Raffino 1981). The platform (9.3 $\mathrm{m} \times 5.8 \mathrm{~m}$ ) is not immediately visible to the eye due to being mainly formed by a natural fill and simple row of stones, partly collapsed. In other places the walls of the platform are obvious and artificial fill can be found inside the structure.

Two stone structures are located inside the platform (Figures 5 and 6 ). The nearly square structure $(1.9 \mathrm{~m} \mathrm{x} 2 \mathrm{~m})$ has walls up to $50 \mathrm{~cm}$. Some tinder was seen at the outside northeastern corner 
Figure 4. Figurine found on the summit of Volcán Taapaca $(5,815 \mathrm{~m}$; 19,073 '). It is made of mullu or spondylus shell in typically Inca style. Miniature cloth and tiny pieces of silver were also found with the figurine.

Figurina encontrada en la cima del volcán Taapaca (5.815 m; 19.073'). Hecha de concha de mullu o spondylus de estilo típicamente Inka. Miniaturas de vestimentas y pequeñas piezas de plata fueron encontradas junto a la figurina.

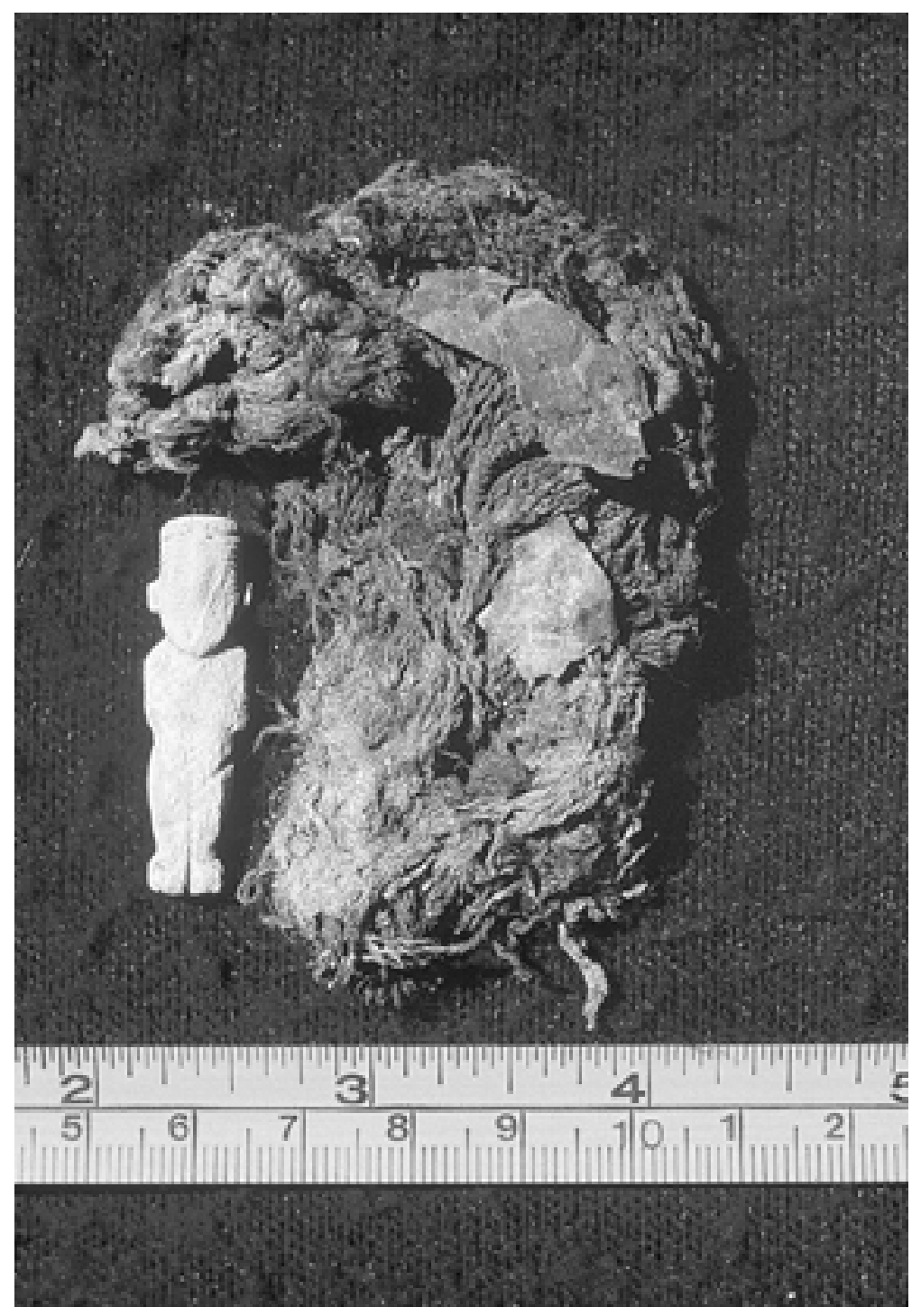

and bone fragments at the interior of the southeastern corner. These most likely had been built in recent times. A large mound of stones $(180 \mathrm{~cm}$ x 160 $\mathrm{cm})$ abutted the structure on its southern side. The other structure $(234 \mathrm{~cm} \mathrm{x} 197 \mathrm{~cm}$ at the main extensions) had walls up to $75 \mathrm{~cm}$ high.

Pieces of wood were found $8 \mathrm{~m}$ to the north and $3 \mathrm{~m}$ to the south of the central structures. Along the east ridge ( $20 \mathrm{~m}$ distant and $8 \mathrm{~m}$ lower in elevation) a low wall (varying 35 to $60 \mathrm{~cm}$ in height) about $4.6 \mathrm{~m}$ long was seen. No diagnostic materials were found which would help to positively date the structures.

The summit of Guane Guane provides an unobstructed view to high mountains in all directions,
Pomerape and Vn. Parinacota being especially prominent to the east (Figure 5) The site was certainly used in mountain worship, not only due to being sacred in itself, but also as a point from which surrounding peaks could be worshipped. We were told that people still today climb up a lower hill on the side of Guane Guane to make offerings to mountain gods during Carnival. The mountains are mainly asked for riches, rain and augmentation of livestock ${ }^{4}$.

\section{Volcán Parinacota $\left(1^{\circ} 10^{\prime} \mathrm{S}, 6^{\circ} 08^{\prime} \mathrm{W}\right)$}

Due to the long drought, the summit of Volcán Parinacota $(6,330 \mathrm{~m} / 20,762$ ') was relatively free of snow and ideal conditions existed for finding 


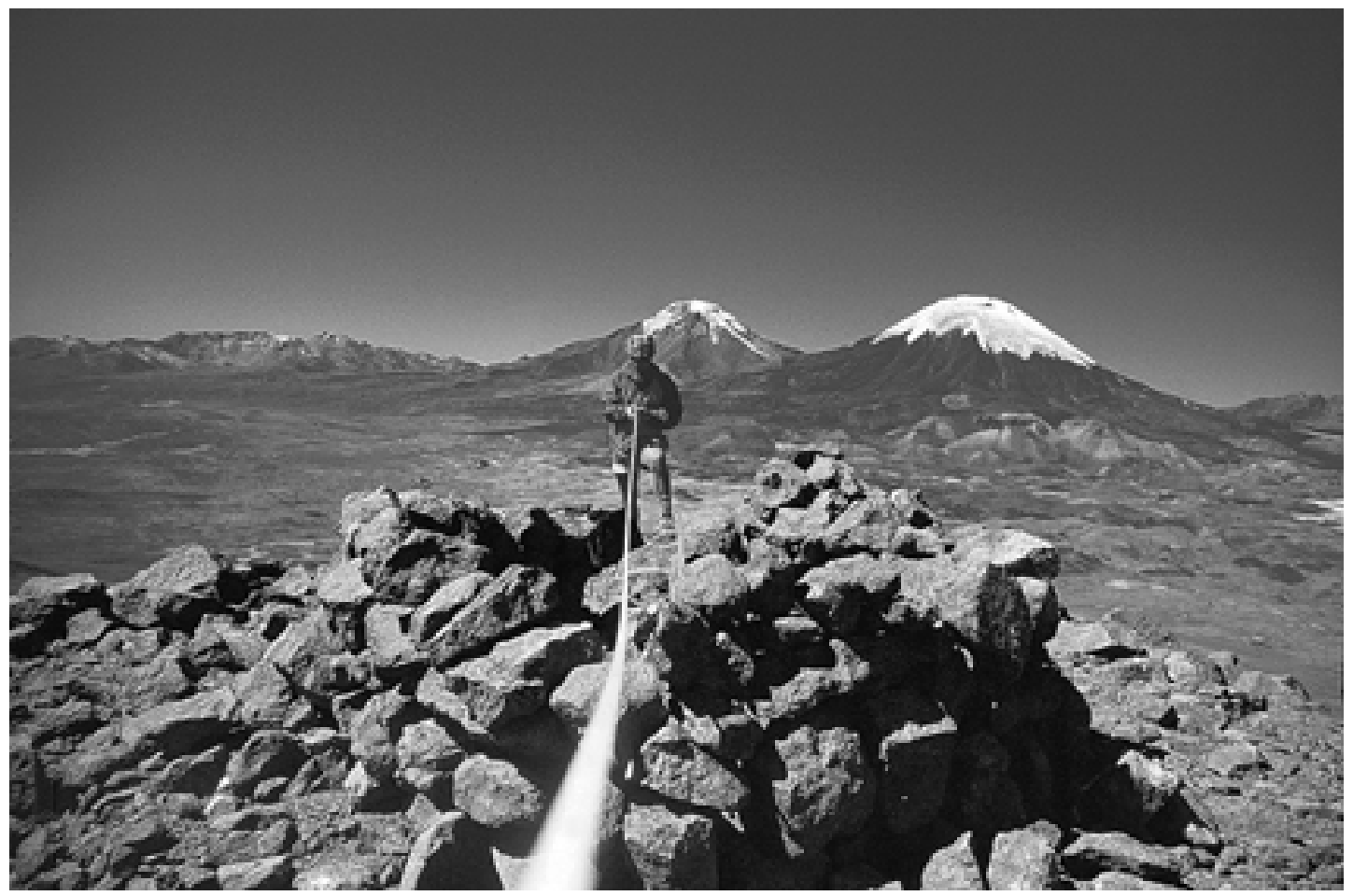

Figure 5. Structures on the summit of the Cerro Guane Guane $\left(5,050 \mathrm{~m} ; 16,564^{\prime}\right)$. Pomerape and Volcán Parinacota are in the background.

Estructuras sobre la cima del Cerro Guane Guane (5.050 m; 16.564'). Se observan los Volcanes Pomerape y Parinacota.

archaeological remains, if any existed. (Figures 7 and 8) Unfortunately, a careful search of the entire crater rim failed to provide positive results.

In local beliefs Pomerape and Volcán Parinacota were believed to be unmarried sisters who refused the attentions of the mountains Sajama and Tacora. They drove off Tacora to its current position far away from them and knocked off its top. Another legend is noted in the mimeographed pamphlet "Información Turística de la Provincia de Parinacota," distributed by the Gobernación Provincial Parinacota. In this legend Pomerape and Volcán Parinacota are also presented as unmarried females who are loved by the mountain Sajama. Sajama fought with Tacora, who wanted to gain their affection. Tacora fled the area, leaving bloody foam at places and a part of his heart. There is a small mountain in the region called Vilachuimane ("bloody heart") and several areas with reddish soil, which local inhabitants believe to have been caused by Tacora's wounds. Due to Sajama being victorious, people believe the area near this mountain became fertile for livestock while that near Tacora became much poorer. Offerings are still made to these mountains during Carnival and (until recently) the May Festival of the Cross. Some people also make offerings on an individual basis on $\mathrm{Au}$ gust 1 , a day when mountains and Pachamama are worshipped throughout the Andes.

\section{Volcán Guallatire $\left(1^{\circ} 25 ’ \mathrm{~S}, 6^{\circ} 06^{\prime} \mathrm{W}\right)$.}

A strong wind kept the sulphur smoke from fumaroles away while I was on the summit of Volcán Guallatire $\left(6,060 \mathrm{~m} / 19,877^{\prime}\right)$, albeit the fumes made it impossible to investigate the entire summit area (Figure 9). However, it is doubtful that any archaeological remains would be found, since only the small area above the fumes is free of permanent snow and the rocks are colored yellow from the sulphur. If the same conditions existed in Inca times, as the evidence suggests, then there is little chance that the Incas would have constructed a site on the summit of this peak.

Nonetheless, Volcán Guallatire must have been worshipped in ancient times, as it is still invoked 


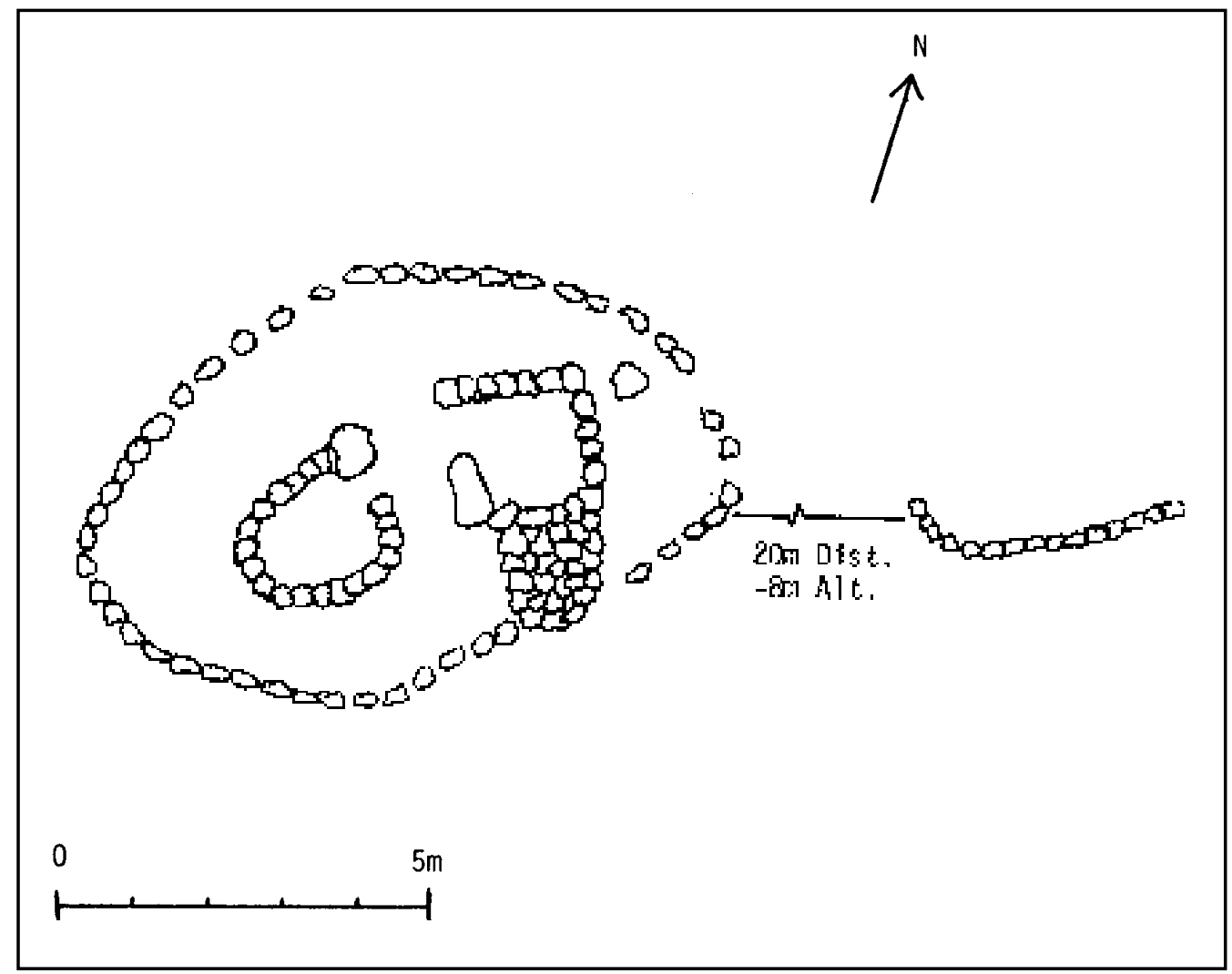

Figure 6. Plan of the summit ruins on Cerro Guane Guane (5,050 m; 16,564'). Plano de las estructuras en el Cerro Guane Guane (5.050 m; 16.564').

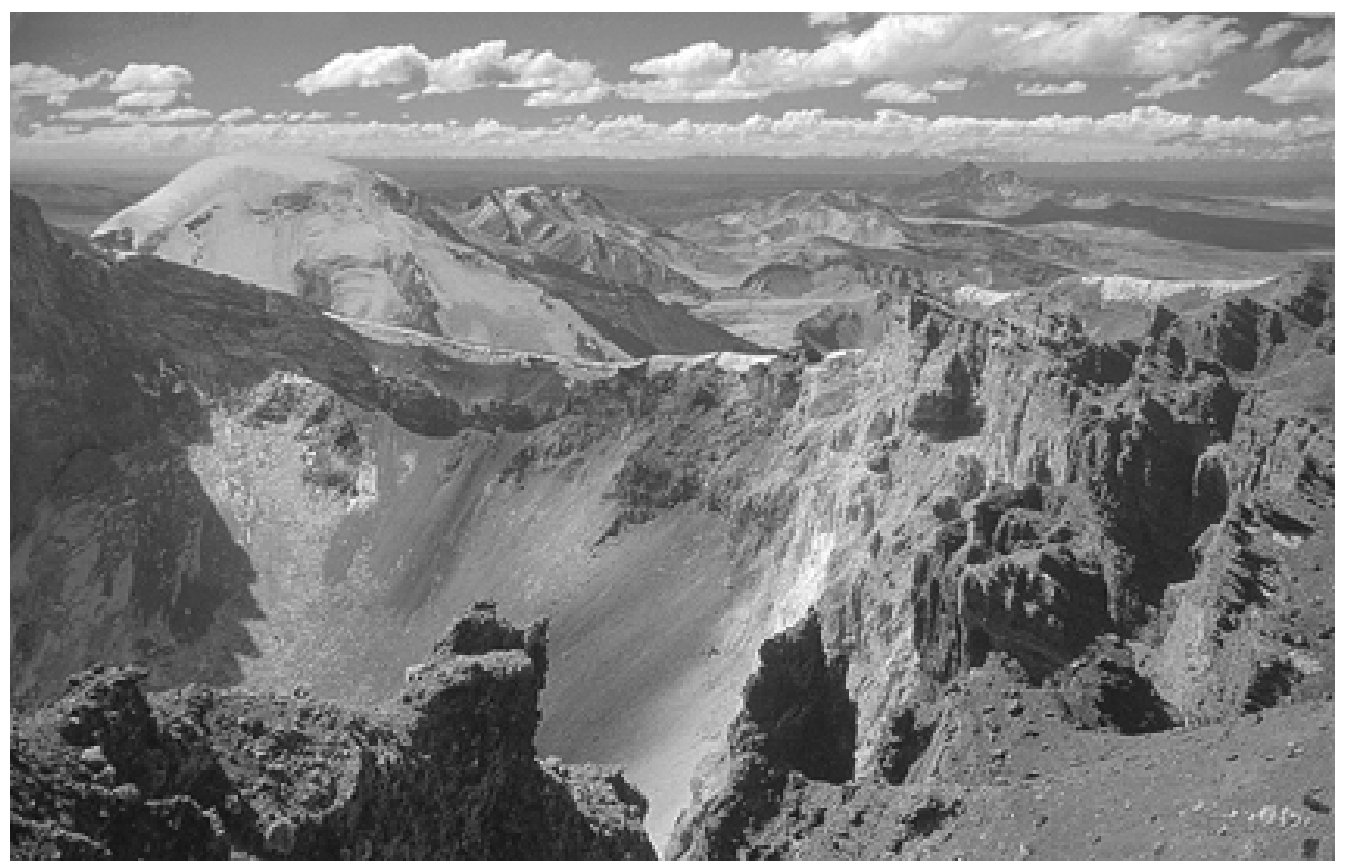

Figure 7. View west towards Pomerape from the summit crater of Volcán Parinacota (6,330 m; 20,762'). Vista oeste hacia el Pomerape desde la cima del volcán Parinacota (6.330 m; 20.762'). 


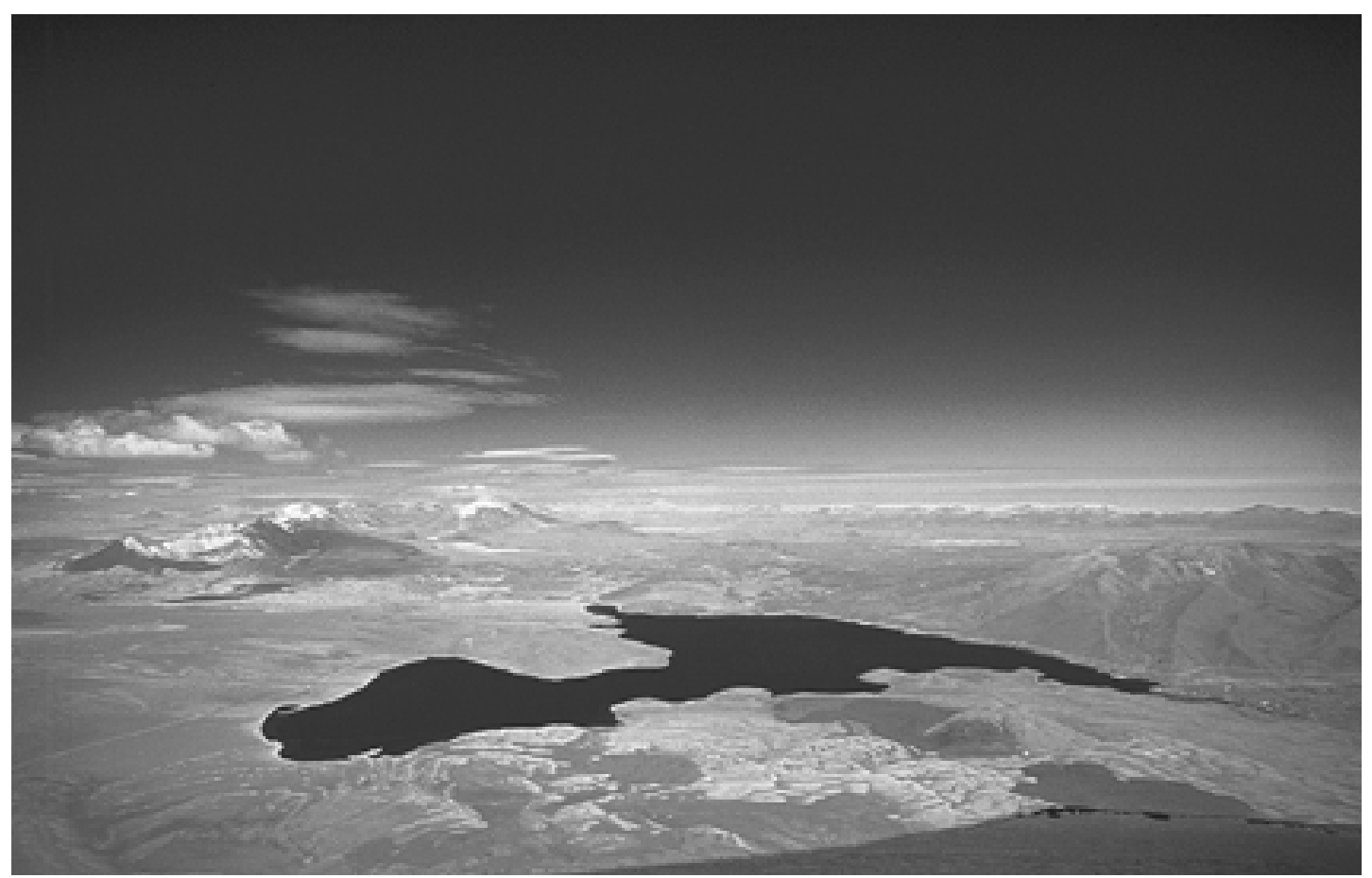

Figure 8. Lake Chungará as seen from the summit of Volcán Parinacota (6,330 m; 20,762'). Volcán Guallatire can be seen left of center and Volcán Espiritus is to the far right.

Lago Chungará desde la cima del volcán Parinacota (6.330 m; 20.762'). Se observan el volcán Guallatire a la izquierda y el volcán Espíritu en el extremo derecho.

in rituals today. The people of Guallatire are said to go to a place near the mountain Capurata (quite close to Volcán Guallatire) every three years during Carnival in order to perform mountain worship (Percy Dauelsberg, personal communication 1983). Even the churches in the villages of Guallatire and Ancuta are oriented toward Volcán Guallatire. Interestingly, Santiago is the patron saint of the village of Guallatire, and the association of Santiago with mountain deities has been widely reported (Fuenzalida 1980).

\section{Volcán Isluga $\left(19^{\circ} 10^{\prime} \mathrm{S}, 6^{\circ} 50^{`} \mathrm{~W}\right)$}

Volcán Isluga $(5,530$ m/18,138') (also called Laram Qhawani) and is one of the most sacred of the mountains in this region (Martínez 1976: 277). Dominating the village of Enquelca, it is no surprise that the local inhabitants consider it to be especially sacred (María E. Grebe, personal communication 1983). Volcán Isluga is thought to be a female spirit which some people believe to be married to the neighboring mountain, Cerro Cawaray
(Cabarray). It is still invoked in rituals for rain, besides being asked for health and riches (Martínez 1976: 277-8; Reinhard and Sanhueza 1982).

Contrary to what we had been told in the village of Enquelga two years before (Reinhard and Sanhueza 1982), there were no large stone ruins on the summit of Volcán Isluga. There was, however, an unusual triangle-shaped symbolic "structure" formed by rows of stones (Figures 10 and 11). It is the first structure of its type to have been noted on a high mountain summit and appears similar to patterns drawn by yatiris (ritual specialists) still today when making offerings to the spirits.

The triangle appears to be pointing west at $280^{\circ}$. There was no prominent geographical feature visible in this direction, only a low "pass" in the hills. However, the southeast tip pointed at Cerro Cariquima (Wanapa), an important sacred mountain of the region. The southern and eastern sides measured $380 \mathrm{~cm}$ and the northern side $410 \mathrm{~cm}$. No diagnostic material was found. Surprisingly, there was also no evidence of an ascent made in recent times. 


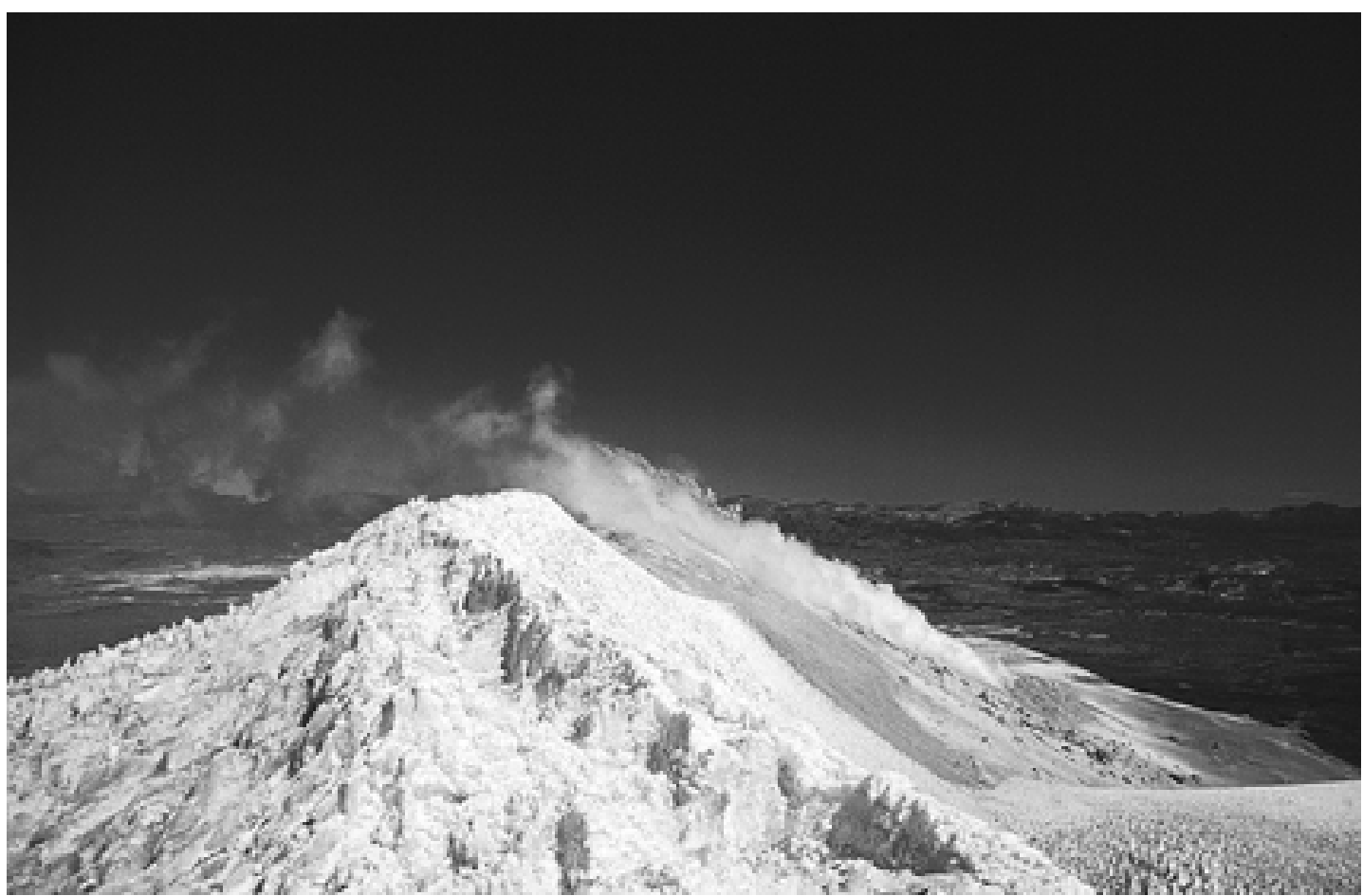

Figure 9. The wind is blowing sulphur fumes over the highest point on the summit ridge of Volcán Guallatire (6,060 m; 19,877'). El viento sopla la fumarola del punto más alto en el borde de la cima del volcán Guallatire (6.060 m; 19.877’).

At ca. 5,200 m (17,056') on the southern ridge of Volcán Isluga we found the remains of structures and wood (Figure 12). Basically, the structures consist of low walls that appear to have served as protective structures (windbreaks) for those who climbed on to the summit (wind coming predominantly from the west). The rectangular-shaped structure had only one well-built wall on the west ca. $80 \mathrm{~cm}$ high, $50 \mathrm{~cm}$ wide and 290 $\mathrm{cm}$ long. Near the north end of this wall was a small niche, $21 \mathrm{~cm}$ wide, $18 \mathrm{~cm}$ high and $35 \mathrm{~cm}$ deep. It was located $30 \mathrm{~cm}$ up from the ground and contained tinder and pieces of thread. It likely had been used for ritual purposes.

\section{Cerro Belén $\left(7^{\circ} 30^{\prime} \mathrm{S}, 6^{\circ} 05^{\prime} \mathrm{W}\right)$}

Structures were surveyed on the summit of Cerro Belén $(5,260 \mathrm{~m} / 17,253$ '). The principal one (3.1 x $4.2 \mathrm{~m})$ appeared to be of recent construction. A cleared area $(3 \times 3.5 \mathrm{~m})$ is located in front of the entrance to the main structure (Figure 13). No diagnostic materials were found, but, given the antiquity of settlements in the area dominated by Cerro Belén, it seems likely that the site is much older than the current structures. The pattern of the ruins is quite similar to that of Inca sites on other summits, and Cerro Belén was probably of ritual significance, not only in itself, but also as a place from which to view higher sacred mountains.

\section{Cerro Marquez $\left(18^{\circ} 44^{\prime} \mathrm{S}, 6^{\circ}{ }^{\circ} 6^{\prime} \mathrm{W}\right)$}

The summit of Cerro Marquez (4,960 $\left.\mathrm{m} / 16,269^{\prime}\right)$ is quite broad and remains of a large structure (ca. $11.5 \times 6.5 \mathrm{~m}$ ) were found. Unfortunately the site had been excavated by looters and the interior divisions of the structure were difficult to distinguish (Figure 14). Light-colored stones from the river below were found scattered around the ruin. River stones have been found at other high mountain sites in Perú (Reinhard 1983) and in Chile (Reinhard and Sanhueza 1982). They were clearly utilized in rituals for water, as they have been found on mountains invoked for this reason still today. A 


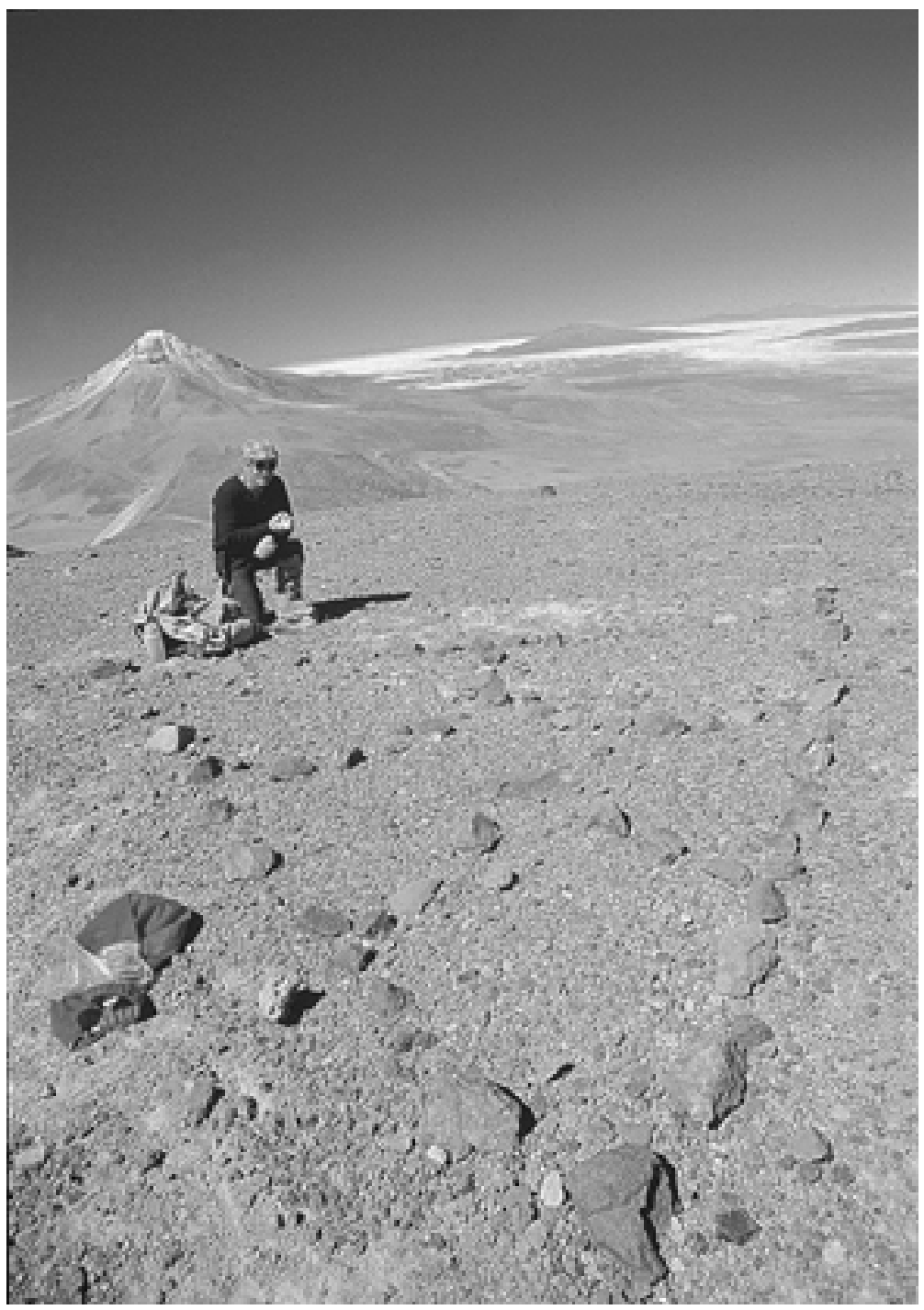

Figure 10. The triangle formed of stones on the summit of Volcán Isluga (5,530 m; 18,138'). Volcán Cabaray is in the background and Salar de Coipasa can be seen in the upper right of the photograph.

Lineamiento de piedras de planta triangular en la cima del Volcán Isluga (5.530 m; 18.138'). Se observa el Volcán Cabaray y el Salar de Coipasa. small stone structure $(1.7 \times 2 \mathrm{~m})$ was found ca. $200 \mathrm{~m}$ to the southeast of the main ruin.

Cerro Marquez (also called Markisa) is considered to be an especially sacred mountain, even being invoked as far away as the village of Isluga (Martínez 1976: 277). Marquez is believed to form a "family" with three other mountains: Itisa, Qolqa and Jachura. These mountains range from near Tignamar in the north to near Chiapa in the south, a distance of about $90 \mathrm{~km}$. We found an important site, of probable Inca origin, on the summit of Tata Jachura in 1981 (Reinhard and Sanhueza 1982). Marquez and Jachura are considered the elder, or more important, members of the "family" (Martínez 1976: 277; see also Keller 1972).

\section{Conclusion}

The ascent of Cerro Marquez terminated the survey of high altitude sites in the region ${ }^{5}$. A total of ten mountains were climbed, six of which were over 5,200 m. Archaeological sites were surveyed and photographed on five of the summits. No excavations were undertaken, but an Inca figurine was discovered on the surface at one of the sites. Ethnographic information collected about beliefs in this region is sufficient to demonstrate that local inhabitants shared beliefs about mountain worship and fertility that are common in many other parts of the Andes (Reinhard 1983). In addition to extending our knowledge of the distribution and types 
A High Altitude Archaeological Survey in Northern Chile

95

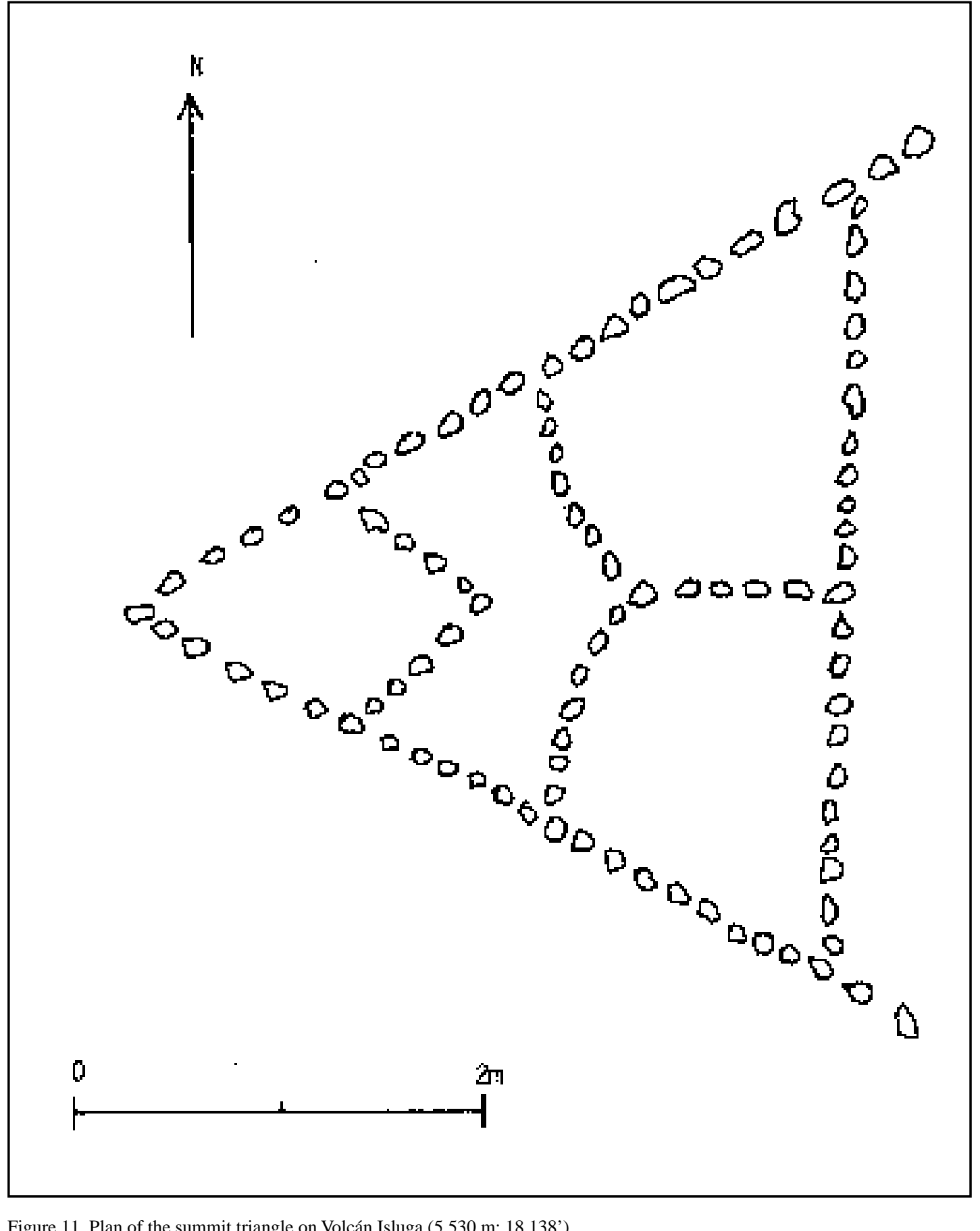

Plano de planta del triángulo de piedras en la cima del Volcán Isluga (5.530 m; 18.138'). 


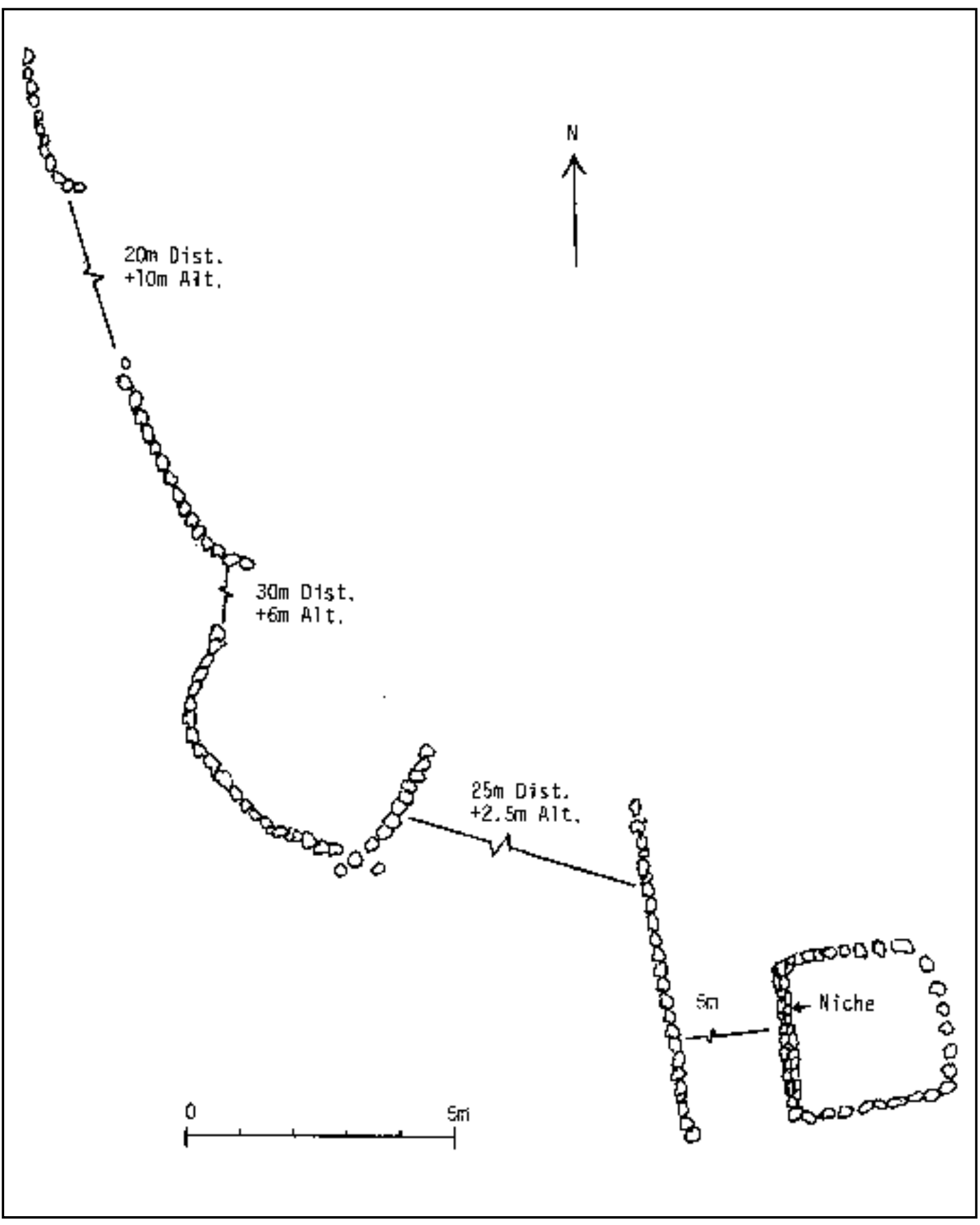

Figure 12. Plan of the structures on Volcán Isluga's southern ridge at ca. 5,200 m (17,056').

Plano de las estructuras en el borde sur del Volcán Isluga a ca. 5.200 m (17.056'). 


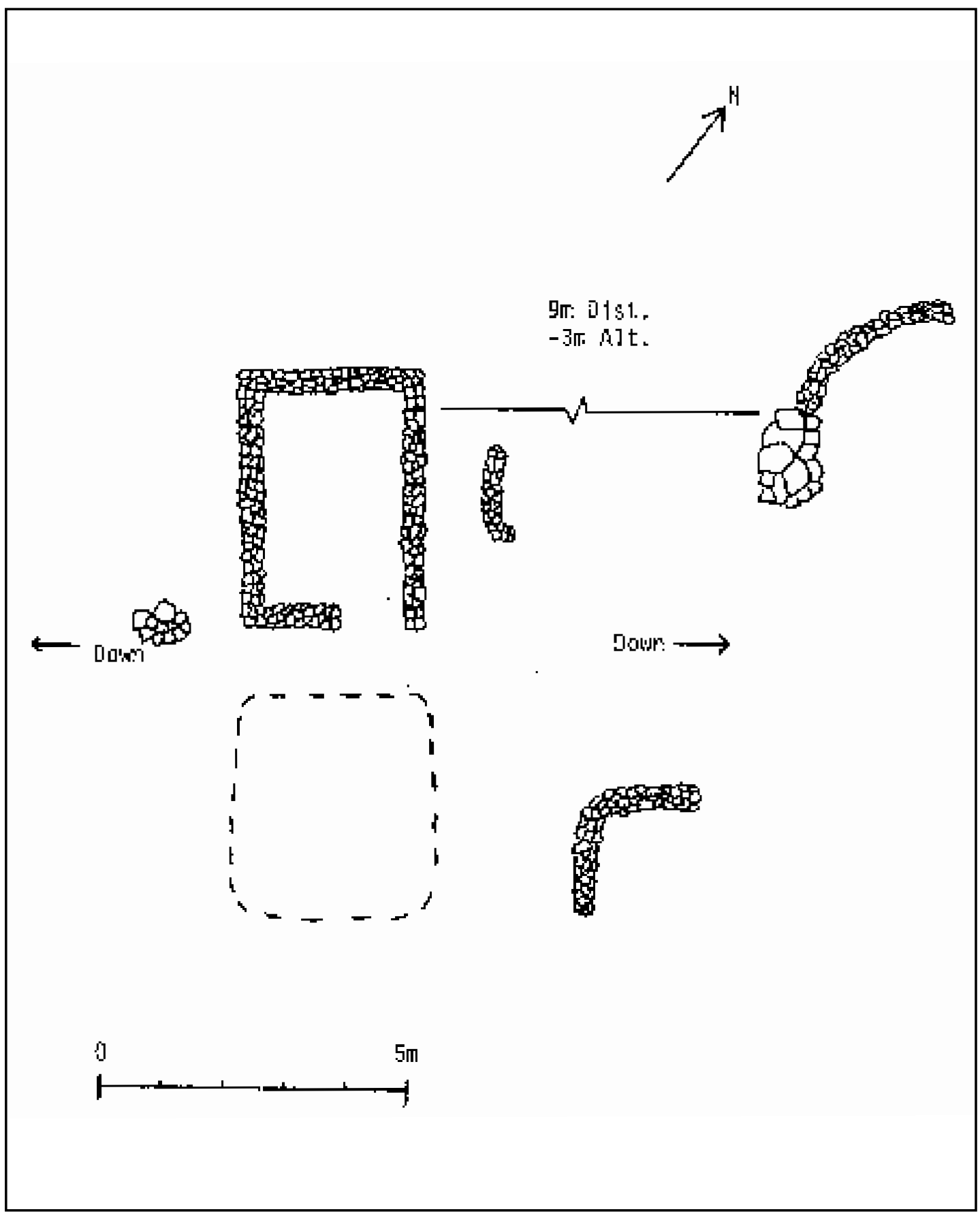

Figure 13. Plan of the summit ruins on Cerro Belén (5,260 m; 17,253').

Plano de las estructuras en la cima del Cerro Belén (5.260 m; 17.253'). 


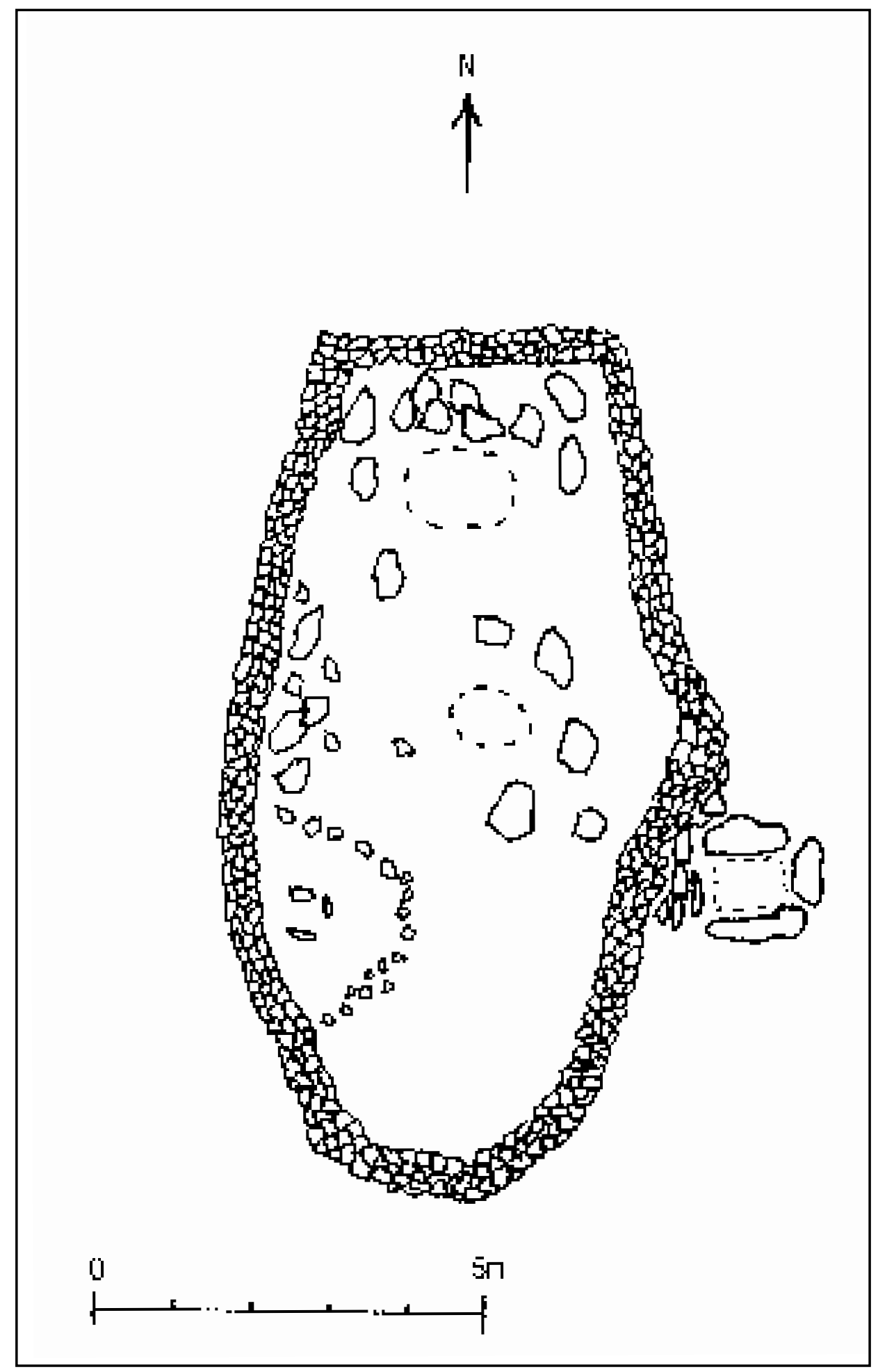

Figure 14. Plan of the summit ruin on Cerro Marquez $\left(5,960 \mathrm{~m} ; 16,269^{\prime}\right)$. The dotted line indicates the area excavated by looters.

Plano de las estructuras en la cima del Cerro Marquez (5.960 m; 16.269'). La línea punteada indica el área excavada por huaqueros. 
of archaeological sites in the region, the survey helped to broaden our understanding of one of the most important aspects of traditional religion of the people who lived (and live) in northern Chile in the area that now lies within the boundaries of Lauca and Isluga National Parks.

Acknowledgements: I would like to thank the Corporación Nacional Forestal (CONAF) for pro- viding a vehicle and driver to reach the bases of the mountains climbed and the Corporación para el Desarrollo de la Ciencia (CODECI), Santiago for supporting my work in northern Chile. My research was funded in part by the National Geographical Society with additional support from the American Philosophical Society. Rob Blatherwick was my companion on ascents of Taapaca, Guane Guane and Isluga.

\section{References Cited}

Barón, A.M. and J. Reinhard

1981 Expedición Arqueológica al Volcán Licancabur. Revista de Corporación para el Desarrollo de la Ciencia 1 (4): 31-38.

Barthel, T.

1959 Ein Fruhlingsfest der Atacameños. Zeitschrift fur Ethnologie 84 (1): 25-45.

Fuenzalida, F.

1980 Santiago y el Wamani: Aspectos de un culto pagano en Moya. Debates en Antropología 5:155-87.

Gobernación Provincial Parinacota

n.d. Información Turística de la Provincia de Parinacota (ms).

Keller, C.

1972 Mitos y Leyendas de Chile. Editorial Jerónimo de Vivar, Santiago.
Martínez. G.

1976 El sistema de los uywiris en Isluga. En Homenaje al Dr. Gustavo Le Paige, SJ, editado por H. Niemeyer, pp. 255328. Universidad del Norte, Antofagasta.

Murra, J.

1975 Formaciones Económicas y Políticas del Mundo Andino. Instituto de Estudios Peruanos, Lima.

Raffino, R.

1981 Los Inkas del Kollasuyu. Ramos Americana, La Plata.

Reinhard, J.

1983 Las montañas sagradas: un estudio etnoarqueológico de ruinas en las altas cumbres andinas. Cuadernos de Historia 3: 27-62.

Reinhard, J. and J. Sanhueza

1982 Expedición arqueológica al altiplano de Tarapacá y sus cumbres. Revista de Corporación para el Desarrollo de la Ciencia 2 (2): 17-42.

\section{Notes}

1 This paper is a summary of a report submitted to the Corporación Nacional Forestal (CONAF) in 1983. The intention in presenting the descriptive material here is solely to make it more accessible to other investigators working in northern Chile. Thus it has not been updated to include more recent archaeological findings, theoretical or material, in the region.

2 In 1981 Julio Sanhueza and I had made an archaeological survey of other peaks in the altiplano of Isluga and Tarapacá, namely Cariquima (Wanapa), Cawaray (Cabarray), Jatamalla, Quetane, Sojalla (Sojay), and Tata Jachura (Reinhard and Sanhueza 1982).
3 The cloth had served as miniature clothing for the figurine and small, flat pieces of silver were also found together with it. These finds were deposited with the Museo San Miguel de Azapa, Universidad de Tarapacá and the textiles were later restored.

4 To the south of the village of Parinacota is a peak called by the suggestive name Espíritus ("spirits") $(5,300 \mathrm{~m} / 17,384$ ') $\left(18^{\circ} 15^{\prime} \mathrm{S}, 6^{\circ} 13^{\prime} \mathrm{W}\right)$. However, I did not observe any structures on its main summit.

5 The nearby summit of Tulapalca $\left(4,780 \mathrm{~m} ; 15,678^{\prime}\right)$ $\left(18^{\circ} 42^{\prime} \mathrm{S}, 69^{\circ} 29^{\prime} \mathrm{W}\right)$ had once had structure that I found to now be completely destroyed. Looters had dug a large hole and thrown river stones off to the sides. 